\title{
TRIM25 Gene
}

National Cancer Institute

\section{Source}

National Cancer Institute. TRIM25 Gene. NCI Thesaurus. Code C20908.

This gene plays a role in transcription and cellular proliferation. The gene is postulated to mediate estrogen interactions in breast cancer. 